\title{
ヒッカケの塗装 $-2-$
}

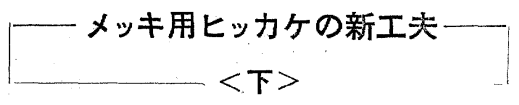

\section{まだエ夫の余地ある常温乾燥塗装}

常温乾燥のヒッカケ専用塗料は, 的 3 年前, すなわちプラスチゾル以前に市肘され，当時 たいていのメッキ工場は, "待望の光沢メッ キ用ヒッカケ塗料が出だととびついたもの であった。この塗料は耐薬品性にすぐれたる ので，セルロイド塗料やテープ巻き絶縁法は 追放したよ5であるが，適正な塗装法が微底 されなかった。 そのために最近では，しかた なくプラスチゾルを外注塗装するようになっ た工場もある。しかし，プラスチゾルを簡単 に採用でさる工場は別として，常に種々ヒッ カケを工作, 改良しながらその特技を売りる のにしている専業メッキ工場や，旧式のヒッ カケで光沢メッキ作業に甘んじていなければ ならなかった小メッキ工場にとっては，限ら れた予算でしか子丈夫に早く手軽く，七ッカ ケの自家塗装がでさる。この常温乾燥塗装法 を無視するわけにはいかない，過去の筆塗リ 方式で中途半端な塗装をしていた頃のヒッカ ケは，耐久性がなかったため，塗料と塗装法が 相当改良されてきた今日でも，"常温乾燥塗 料は使いものにならない”と考党ている人る 多いようである.・しかし，各施工者がこの常 温乾燥塗装法を工夫することによって, 過去 の活名を返上できるならば，ヒッカケの優劣 が直接生産性を左右している現在のメッキ専 業工場に，もっと合理的なヒッカケの普及を 早めるのではなかららか。

\section{薄い塗膜では長持ちしない}

ヒッカケのすぐれた叙装法を一口にいえ ば，適切な厚サの塗膜を均一に被覆すること である.またヒッカケには, 丸材のものから 角材のもの，バネの伸縮が大きいるのから小
鵜䣳技術事務所内 田 大

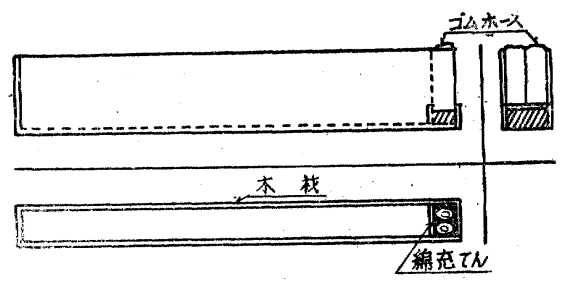

第 1 図 (A)

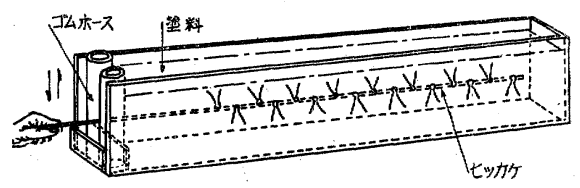

第 1 図 (B)

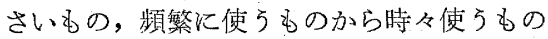
と種々雑多であるが，それぞれの条件にかな った厚サの塗膜を施すべきで，これらをすべ て同じ膜厚で塗装することは不合理である.

常温乾燥塗装では，焼付塗装のよにに一回 のディップ塗装で厚い塗膜を得ることはでき ないから，怣際には，塗膜が薄くなることは めっても，憬くなり過ぎることは少ない、筆 者はヒッカケ塗装の標準膜厚をつぎのよ5に 考えている.

1 級叙膜一 $0.8 \sim 1.0 \mathrm{~mm}(10 \sim 13)$

2 級叙膜一 $0.6 \sim 0.8 \mathrm{~mm}(8 \sim 10)$

膜厚測定は, 完全乾燥後に平板の中心部で 行な5.（）内の数字はディップ回数を示 す.この回数は塗料濃度およびヒッカケの構 造に左右されやすい.10回以上のディップ操 作を忠奏にくり返すことは非常に面倒である が, 初めに 1 級塗膜に塗装したヒッカケは, 常用しても 1 年くらいではほとんど故障がな 
い. 1〜2 カ月でキ裂, 塗膜のハク離したもの は，たいてい2 級塗膜より粗雑な塗装のもの が多い. 塗膜が所定の厚サよりわずかに薄い だけで，その寿命はずっと短くなるものであ るが，逆に所定の厚サよりわずかに厚くして 相当に長持ちさせることがでさる. 初めに 2 級塗膜に叙装してある期間使用し，塗膜のキ 裂を認めてさらに2〜3回ディップ塗装する こともあるが,ひんぱんに使われるヒッカケ は，多少厚めに塗装することが望ましい。

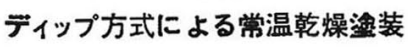

a) 塗料濃度の調整一一従来の筆叙り方式 は均一な塗膜が得られないばかりか, 塗装能 率も悪いので,本稿ではディップ方式(浸セキ 塗装方式）を紹介する. 塗料槽には綐型と横 型の 2 種あるが，横型槽が実用的である.デ イップ前にはヒッカケの清浄化 (前号参照) そ塗料濃度の調整を忘れてはならない. 濃度 の適・不適は塗膜の均一性と叙装能率に淔接 関係するから，常に適切な濃度に管理してお く. 一般に高濃度 (高粘度) の塗料は, ディ ップ回数の前半か, 枝骨の樦造の単純なもの に使われる.

ディップ回数の後半または枝骨構造の複雑 なるのに馿れない施工者が行なら場合は，低 濃度の塗料でディップ回数を多くすることを すすめる、第 1 図の模型塗料槽は, 塗料容積 を最小量に止めて最も経済的に塗装するため に工夫されたものである.ディップ法は写真 1 で分るよ5に，槽の側面に立てた 2 本のゴ ムホースの間に親骨の一部を押し込みなが

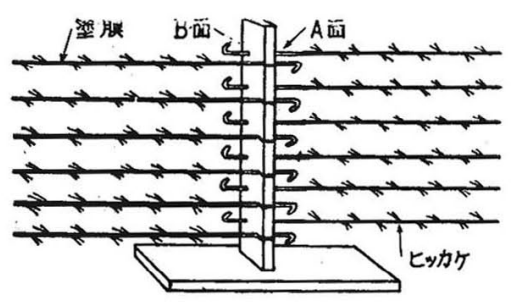

第 2 図

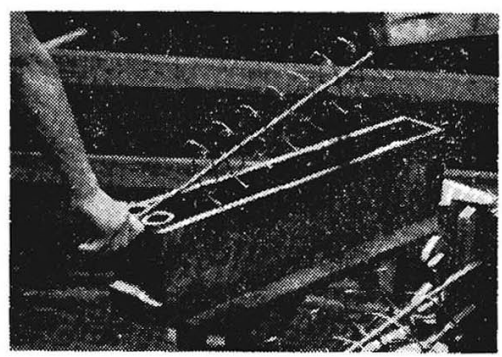

写真 1 ディップ塗装現場

ら, 叙膜に気泡を持ち込まぬ上うにヒッカケ を塗料にディップする. 塗装中に溶剂は揮発 して徐々に高濃度になるから, 施工者は専用 シンナーを常備して適宜濃度調整を行なわな ければならない。普通のディップ方式では, 消費塗料と同量の希瀵用シンナーを用意すれ ばよい。

b ）過剩の塗料は落す一一塗料標から引き 上げたヒッカケになるべく厚い塗膜を均一に 乾燥させるには，1回のディップで付着させ る塗料の適量を心得て执き, 過剩の分悇料 槽に落して回収しなければならない。1回の ディップで塗料を付け過ぎると不均一な塗膜 になりやすいし、塗料を落し過ぎても塗装能 率が悪くなる. 施工者はこの操作に早く熟練 する必要がある.

c）均一な塗膜に早く安定させる一ーディ ップ後の塗膜は未乾燥の状態で非常に不安定 であるから,ちょっとの間もヒッカケを一定 方向に静止させて置くことがでさない。ディ ップ後 $2 \sim 3$ 分間で表面の塗膜は半かわきに なり, 溶剤の揮発とともに安定してくるが, このような状態になるまでは，ヒッカケをク ルクル迴したり，上下に動かしたりしながら 塗膜を均一に安定させるのである. ある程度 安定したものは, 第 2 図の水平乾燥台に順次 かけていく.(この乾燥台で5〜6分すれば, 垂直につるして乾燥してもよい). なお，水 平榦台を用いても塗装速度を上げると多少 下側飞塗膜は厚くなりやすいから，施工者は 
ヒッカケのA面，B面を印して持きディッ プ回数が奇数のときはA面を上に，偶数の時 はB面を上に，と両面を交互に上向きにかけ るとよい，塗膜を均一にするためのこれらの 操作は個人差もあるから，一貫して同一施工 者によって塗装することが望ましい.

d）塗膜の光沢は天候によって变わる ヒッカケの塗装で光沢面を得るには塗料の乾 燥条件に注意しなければならない. 雨天の時 や真冬の午前中など特に条件の悪い場合は, 室内でなるべく塗料に引火しにくい電熱スト 一ブなどを用いて乾燥するが，普通には，日 当りと風通しのよい乾燥場であれば簡単に光 沢が得られるものである.

\section{セルロイド膜による塗膜補強の一例}

常温乾燥塗料の欠陥をしいてあげるなら ば, 高熱工程に耐えないことである. 手作業 のメッキ作業工程ではこのような支障も少な いが，自動化された乾燥工程では注意しなけ ればならない.つぎのセルロイド塗膜による 補強は,強制乾燥工程に効果はないが,一般の メッキ作業工程の高温銅メッキや熱湯浸セキ 乾燥, あるいは有機溶剤のエマルション溶液 浸セキ程度であれば. 叙膜の損傷を軽減する 効果がある.補強セルロイド膜の塗装法は,前 項のディップ塗装と同じ方式でよい. 塗料は ニトロセルローズを有機溶剤で溶かした異種 のものであるから, 塗料槽は絶対に混用して はいけない.ヒッカケのビニル塗料が完全に 乾燥した後, 本塗料で 1 ～ 2 回ディップすえ ば十分である．乾燥速度がきわめて速いの

\section{(42ページよりのつづき)}

それゆ作業研究は，むしろ中小企業こそ 大企業にもまして実施しなければならないる のということができるなんとか工夫をこら して実施しなければならない。たとえば多種 小量で，つぎからつぎへと新らしい図面で仕 事をしている，試作工場的な場合でも，一定 の設備で一定の人が生産をしている以上, 細

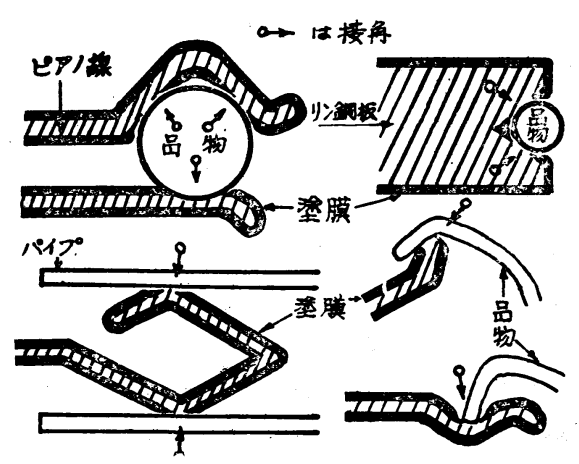

第 3 図

で20分後には接点を露出して使用できる.

\section{接点の露出は入念にする}

接点構造を工夫したヒッカケも, 接点の露 出に失敗すれば価值を半減する場合が多い。 たいていの工場では，ヒッカケの製作や塗装 は馴れた施工者が行なっていても, 接点の露 出作業は間に合わせの者によって行なわれて いることが多い.これでは理想接点方式を 十分活用できなくなってしま5。第3図は小 物・中物ヒッカケの理想接点の露出例であ る.このように面倒な塗膜切除には，特に鋭 利な刃物を用いてうまく行なわないと塗膜の 切口を傷つけやすい. ピアノ線専用の切除用 具としては, 電線ストリッパーに似た型式の ものを線の径に合わせて用いると能率的であ る. 特種な接点構造のものには, 丸, 角, 半 丸などのヤスリによって塗膜の切除がスム一 スにできることもある. 常温乾燥塗装の工業 実験には，商品名「フロンテックス」（製造 元 古藤産業株式会社）を使用した。

かく分析してみれば，必ず共通の作業もある はずであるから，これには作業研究を実施す ることがでさるのである.

どうしても実施できないような工場でも， その工場の管理者は作業研究のいかなるもの かは，わきまえておく必要がある。

そこで作業研究の実際を，まず動作時間研 究の初歩から順を追って学ばねばなるまい。 